\section{Robert Paul Boynton}

Robert Paul Boynton (universally known as Bob) died of cancer on November 4, 2005, at age 78. Bob was a collegial colleague, constructive collaborator, compassionate confidante, and consummate cosmopolitan. These alliterative categories attempt to capture the primary qualities of Bob's 50 years of scholarly public life. The designations, however, fall woefully short of encompassing what he contributed to numerous university, association, community, national, and international settings. In those contexts his personal, intellectual, and humane character and skills stimulated good will as well as good learning.

In more conventional categories Bob could be identified as an outstanding teacher, researcher, administrator, consultant, traveler, and seaman first class (more on this later). He grew up in Grand Rapids, Michigan and after a brief hitch in the Navy, he attended nearby Calvin College on the GI Bill. Following his B.A. degree Bob entered graduate school at the University of Michigan in 1949 during the early roots and heady days of the behavioral revolution in political science. After completion of his dissertation on Santayana (A Poetic Approach to Politics) he taught briefly at Wells College (1954-1957) before returning to the Midwest to teach at the University of Iowa (1957-1969).

Bob's disciplinary interests in political theory and philosophy did not make him hostile to new and constructive developments in the discipline generally and to subfields beyond theory. He was neither a stranger to nor an opponent of quantitative approaches in political science and public administration. From Ferrel Heady at Michigan he developed a career-long interest in comparative and development administration. Public administration became his adopted field and it drew him along pathways smoothed by the footsteps of Dwight Waldo and others.

Bob joined the American University faculty in 1969 to direct the public administration program in what was then the School of Government and Public Administration. A thinker and a philosopher of education, he quickly proved as well to be a program organizer, an innovator, and a supporter of strong practitioner-academic relationships. His organizational skills were quickly recognized when he was tapped to serve as dean of Graduate Studies and Research
(1970-1974). As graduate dean he quickly determined that the office did not need to exist. In a strong move toward the decentralization of academic decision-making he secured the abolition of the graduate deanship and the devolution of its duties and responsibilities to the university's schools and colleges.

During this period, Bob also served as a de facto assistant vice-president for academic affairs, consulting with the vice president and the provost on faculty personnel matters, academic budget, and academic planning and development. $\mathrm{He}$ subsequently served in several formal administrative roles, including director of the Public Administration Program, director of the Center for Urban Policy Analysis, director (for 10 years) of the Center for Technology and Administration, and chair of the Department of Public Administration. He moved to "retirement" status in 1995 but continued teaching and was serving as interim chair of the Public Administration Department when a recurrence of cancer overtook him.

Bob's talents as a teacher as well as an administrator at American were widely recognized. Prominent among his teaching subjects were courses on Comparative Administrative Systems, Administration of International Programs, Organization Theory and Behavior, and Nonprofit Sector Management. A popular and personable professor, his courses were especially attractive to international students from developing countries. In addition to diverse course offerings he chaired 24 doctoral dissertations including some that received national awards.

Bob's international consulting and advisory responsibilities were extensive for the World Bank, the United Nations, USAID, and the Institute of Public Administration (New York). These roles took him to Indonesia, Yemen, Oman, Pakistan, Russia, Estonia, Latvia, Lithuania, and Ukraine. His domestic consulting roles were likewise diverse and included the following federal agencies: Agriculture, Labor, Transportation, Office of Personnel Management, and Federal Railroad Administration. He also served as a frequent lecturer for the following organizations: Federal Executive Institute, Federal Executive Seminar Centers, Presidential Management Internship Program, International City/County Management Association, Council of State Governments, Institute of Social Studies (the Hague, Netherlands), and the University of North Carolina at Chapel Hill.

Bob's knowledge and experience in higher education called on him to serve in numerous and varied capacities. Representative of these were: Woodrow Wilson Fellowship Program, Muskie Scholars Program, Humphrey Fellowship Program, President of Pi Alpha Alpha National Honorary Society, the National Association of Public Affairs and Administration, and Public Administration Fellows Selection Committee.

Bob was a published scholar with articles appearing in the Journal of Politics, Journalism Quarterly, Municipal Yearbook, Public Administration Review, and Public Management. He was a member of the American Political Science Association, American Society of Public Administration, Midwest Political Science Association, and Southern Political Science Association.

He is survived by his wife, Dolores Boynton of Rockville, MD, daughter Carla of Milton, DE, two brothers, a sister, and several nieces and nephews. In recognition of his distinguished service at American University the Robert P. Boynton scholar award has been established at the School of Public Affairs. Contributions may be made to: Robert P. Boynton Award, School of Public Affairs, American University, 4400 Massachusetts Avenue, NW, Washington, D.C. 20016.

At his memorial service held last December in Washington, D.C., Bob's connections with poetry and seamanship were celebrated with final lines from Tennyson's poem, "Crossing the Bar."

For though from out our borne of Time and Place

The flood may bear me far,

I hope to see my Pilot face to face

When I have crost the bar.

Bob so successfully navigated this side of the bar that he has surely met his Pilot safely on the other side.

$$
\begin{array}{r}
\text { Robert E. Cleary, } \\
\text { American University } \\
\text { Deil S. Wright, } \\
\text { University of North Carolina at } \\
\text { Chapel Hill }
\end{array}
$$

\section{Fred Homer}

Fred Homer, a political science professor at the University of Wyoming, died of heart failure on January 1, 2006, at the age of 66 . 
Fred was born on Long Island on June 9, 1939. He married his high school sweetheart Carole Krane in 1961. That year he also received his A.B. in economics from Rutgers University. While at Rutgers he played basketball and throughout his life maintained an active interest in competitive sports of all kinds.

Prior to entering academe, Fred served as a first lieutenant in the Army and subsequently worked for a short stint as an accountant at Price Waterhouse. However, his real interest was in academe, specifically political philosophy. In the mid-1960s, he began studying for his Ph.D. at Indiana University under the tutelage of Charles Hyneman and graduated in 1970. After receiving his degree, Fred taught at Purdue University until 1974.

In 1974, he began teaching at the University of Wyoming, where in his early years there he established the Administration of Justice Program, which he chaired for 10 years. Today, the renamed Criminal Justice Program is one of the most popular degrees at the University of Wyoming. He also served as the head of the political science department from 1976 to 1979 and as acting head of the journalism and telecommunications department from 1986 to 1987.

Fred was an outstanding teacher. He was noted for his ability to inspire his students through his use of the Socratic Method. He taught the political science department's Introduction to Political Thought; a course on Political Violence that examined, in particular, the Holocaust; several senior seminars on political philosophy; and, in recent years, a very popular course on city politics. Throughout his career, he won many awards that honored his teaching, including the Ellbogen Teaching Award, the Case Wyoming Professor of the Year Award, and the Alumni Teaching Award.

Fred Homer was also a prolific researcher, with four books to his credit. Early in his career, he wrote Guns and Garlic: Myths and Realities of Organized Crime, which won recognition from the American Scholar as one of the best social science books by university presses in 1974-1975. He also wrote Character: An Individualistic Theory of Politics in 1983, which later guided him in his political career in city politics. His book Interpretation of Illness, published in 1988, examined what he believed is often the psychological reason for physical illnesses. His last book Primo Levi and the Politics of Survival, published in 2001, pursued his life-long interest in the Holocaust.

In recent years, he also wrote articles on university politics, one of which ap- peared in this journal. He also recently wrote articles that appeared in Humanity and Society, Journal of Public Administration Education, and Public Administration and Management. In addition, he wrote a short story published in Public Voices.

Fred was very active in his community. At an age when many people are retiring, Fred chose instead to run for public office. In 2000, he was elected to the Laramie, Wyoming, City Council, where he was subsequently elected by his peers to be vice mayor, a position he held from 2000-2002. In 2002, he became mayor, a position he held from 2002-2004. During his tenure as mayor, he was instrumental in bringing about a smoking ban in public places and also in building the city's recreational center.

Fred is survived by his wife Carole; his son Scott and wife Chanisa and their daughter Esther; his son Marc and wife Azize and their son Rafael Ozan; and his daughter Laurie and husband Rodney Wambeam and their three children London, Hazel, and Ruby.

The University of Wyoming has established the Fred Homer Memorial Fund, the endowment of which will further the teaching of political philosophy at the University. Those who would like to contribute to the Fund should send a check made out to the University of Wyoming Foundation to the following address:

University of Wyoming Foundation 1200 E. Ivinson

Laramie, WY 82070

\section{Larry Hubbell \\ University of Wyoming}

\section{Woodrow Jones, Jr.}

Woodrow Jones, Jr., professor of political science at Texas A\&M University passed away on November 22, 2005, after a long battle with heart disease. Born in McKenzie, Tennessee, on February 28,1947 , he received his B.A. in political science from the University of New Mexico in 1969 and went on to earn an M.A. and Ph.D. in political science from the University of Oregon in 1974 and an M.P.H. from the University of Texas School of Public Health in 1981.

Woody began his academic career at the San Diego State University in 1974 and moved to Texas A\&M University in 1988. An expert in the politics of health policy, his work focused on questions of racial equity in the U.S. health care system. Woody and his long time coauthor, Mitchell Rice, were the authors of Blacks and American Government: Politics, Policy, and Social Change (with
J. Owens Smith); Black American Health: An Annotated Bibliography; Health Care Issues in Black America; Public Policy and the Black Hospital; Health of Black Americans from Post Reconstruction to Integration, 18711960; and Contemporary Public Policy and Black America. He was also the coauthor (with Paul Strand) of Indochinese Refugees in America: Problems of Adaptation and Assimilation. He and Rice were among the first contemporary African-American political scientists to examine African-American health care from a politics/policy perspective. In his books and numerous articles and book chapters, Woody systematically documented the inequities in health care in America, providing systematic evidence of two health care systems, one for Blacks and another for Whites.

Woody's scholarly career was interrupted at Texas A\&M when he moved into administration, serving as associate dean of the College of Liberal Arts (1988-1993), interim dean of the College of Liberal Arts (1993-1994), and dean of the College of Liberal Arts 1994-2001. He was the first African American to serve as dean at Texas A\&M University. As dean he championed the arts and was instrumental in creating the Department of Performance Studies and added degree programs in music, telecommunications, and American studies as well as a new Ph.D. in speech communication. The College of Liberal Arts, he contended, was the "heart and soul" of the University. The college also created a Center for Humanities Research, now the Melbern G. Glasscock Center for $\mathrm{Hu}-$ manities Research. Woody also laid the ground work for the creation of a Phi Beta Kappa chapter at Texas A\&M and was instrumental in the creation of the George H. W. Bush School of Government and Public Service. His leadership in administration went beyond Texas A\&M when he co-founded the Texas Association of Deans of Liberal Arts and Sciences and served as its president in 1999-2000.

As dean at A\&M Woody was a strong advocate for diversity in both the student body and among the faculty. When he stepped down as dean, he co-founded the Black Faculty Alliance and served as its first president. At the time of his death he was working to create an Africana Studies Research Center at Texas A\&M.

Woody returned to teaching in the department of political science after his service as dean. His long battle with heart disease took a serious toll, and he eventually received a heart transplant. $\mathrm{He}$ returned to teaching after the transplant and was teaching undergraduate classes 
in health policy and urban politics at the time of his death. Although his closest friends advised him to slow down and take it easy, he restarted his research agenda, working on a new book on The Politics of Black Health Care, and proposing conference papers on race and policy issues at political science conventions.

Woody's life was characterized by passion and humor. He was passionate about issues, particularly the need for greater diversity at colleges and universities. Woody knew that race played a major role in his life, and he was sensitive to how it shaped the life chances of others. He also had a great sense of humor. His students will remember him as a down-to-earth professor who cared about them as individuals. He even brought his humor to the classroom. Outside the classroom with friends and colleagues, one could sit and have a drink (or maybe two) with Woody and spend the entire time laughing, not ever realizing that he was your dean. Woody will indeed be missed.

Woody is survived by his wife, Mary Wolf, two daughters, Kamilah and Halimah, a grandson, Torrence Woodrow "Little Woody" Brown, and his parents, Woodrow Sr. and Florence Jones.

\section{Patricia Hurley Kenneth Meier Mitchell Rice Texas A\&M University}

\section{Richard L. Merritt}

Richard L. Merritt, Emeritus Research Professor in Communications and professor of political science at the University of Illinois at Urbana-Champaign, died on Saturday, November 19, 2005. He had suffered from Parkinson's for several years and fell at his home a week before his death.

"Dick," as he was known to his friends and colleagues, was born on $\mathrm{Au}$ gust 8, 1933, in Portland, Oregon. He graduated Phi Beta Kappa with a Bachelor's degree in international relations from the University of Southern California in 1955. He studied at the University of Virginia, Free University of Berlin, and Yale University, where he received his Coctorate in 1962 under Professor Karl Deutsch with whom he collaborated throughout Professor Deutsch's academic life.

Dick taught at Yale University and, since 1967, at the University of Illinois at Urbana-Champaign. As head of the department of political science (19781984), Dick's tireless recruiting initiatives strengthened the department's research and teaching capability, notably in quantitative international relations research. During his tenure, he was principally responsible for creating the Merriam Laboratory for Analytic Political Science. In 1976, he was visiting professor at the Free University of Berlin, where he had earlier (1966-1967) been Fulbright research professor; in 19791981, visiting scholar at the International Institute for Comparative Social Research, Science Center Berlin; in 1991, visiting professor at Rhodes University, South Africa; and in 1992-1993, Fulbright research professor at the Humboldt University of Berlin. He lectured (in English and German) at major universities and government institutions on five continents.

Dick served as vice president both of the International Studies Association (1979-1980) and the International Political Science Association (1979-1982), and as president of the ISA/Midwest (1984-1985) and the Conference Group on German Politics (1986-1988). He organized the annual meetings of the American Political Science Association (1970) and International Studies Association (1973) as well as the triennial world congress in Moscow of the International Political Science Association (1979). He co-organized the inter-university Data Development for International Research (DDIR) group. He edited IPSA's book series and served on a dozen editorial boards of professional journals, including the International Political Science Review, Political Communications, Historical Social Research, and the American Journal of Political Science. He consulted for the United Nations and for government agencies and educational institutions in the United States and West Germany. In 1975 he received the Wakefield Award for Outstanding Political Achievement, from the University of Illinois at Urbana-Champaign. He is listed in Who's Who in America and other directories.

Dick, a pioneer in the quantitative study of international relations, was a leader in research and teaching in international communication and politics. His authored and edited books on international communication include Symbols of American Community (1966), Communication in International Politics (1972), Communication and Interaction in Global Politics (1987), and Science, Politics, and International Conferences (1989). Books written or edited on quantitative international politics include Comparing Nations (1966), Systematic Approaches to Comparative Politics (1970), From National Development to Global Community (1981), and Theory and Management of International Event Data (1992).

Dick was no less internationally recognized as a leading scholar and policy analyst of German government and politics. Books written or edited on postwar Germany include France, Germany and the Western Alliance (1967), Public Opinion in Occupied Germany (1970), West Germany Enters the Seventies (1971), Public Opinion in Semisovereign Germany (1980), Living with the Wall (1985), and Berlin Between Two Worlds (1986). In 1995 Yale University Press published his Democracy Imposed: U.S. Occupation Policy and the German Public, 19451949. In the course of his rich and creative career, Dick authored or coauthored seven full-length volumes and contributed more than 100 articles and 50 reviews to scholarly journals and books.

Dick has left an indelible mark on his fields of specialization. These are living testimony for what he will be remembered most-and best: his uncompromising dedication to high intellectual and academic standards; his significant contributions to international relations theory, methodology, and practice; his exemplary and unselfish professional service; his devotion to teaching excellence; and his unwavering support of his beloved family, cherished friends, and valued colleagues.

Dick will also be remembered by his close friends and family for his quiet manner and sardonic wit, as well as his great love of classical music, movies, bicycling, dark chocolate, and cats.

Dick is survived by his wife, Anna Gode-von Aesch Merritt, whom he met when both were in Berlin as Fulbright students and with whom he co-authored and co-edited a number of books and articles. Survivors also include three children, Christopher (San Diego), Geoffrey (Urbana), and Theodore (Urbana), a granddaughter, a grandson, and two brothers, Col. Raymond James, USAF/ ret. (Marysville, CA), and John (Berkeley).

Family, friends, and colleagues around the world-we all will miss him.

Edward A. Kolodziej
University of Illinois,
Urbana-Champaign

\section{William C. Mitchell}

William C. Mitchell died January 2, 2006, at his home in Eugene, Oregon. He had suffered from pulmonary fibrosis. He was 80. His wife since 1959, Joyce Mitchell, died in 1996; he is survived by a brother James W. Mitchell, of Kingsford, Michigan, and two sisters, Jeanine 
Watt of Iron River, Michigan and Waverly Jarvis of Withee, Wisconsin.

Mitchell-Bill as he insisted to students, colleagues and friends-served with the $513^{\text {th }}$ Parachute Infantry Regiment of the $17^{\text {th }}$ Airborne during World War II, making several combat jumps, including Operation Varsity, the largest airborne jump ever, on March 24, 1945, during the crossing of the Rhine. After the war, he completed a B.A. in economics from Michigan State University (1950), an M.A. in political science from the University of Illinois (1951), and a Ph.D. in political science from Harvard University (1960). He was an APSA Congressional Fellow in Washington between 1957 and 1958, where he first met Joyce Coward from Berkeley, also a Congressional Fellow, who he subsequently married. He and Joyce accepted positions in the political science department at the University of Oregon in 1960 where he was promoted to full professor in 1965. He taught there until his retirement in 1995, although with visits to the Center for Advanced Study in the Behavioral Sciences, Stanford (1966-1967), the Center for Study of Public Choice, George Mason University (fall 1991), and elsewhere. In 1988 he was the first person elected as a Distinguished Fellow of the Public Choice Society.

Bill's early work took cues from one of his two great mentors at Harvard, Talcott Parsons (the other was V. O. Key). In an early paper, "The Polity and Society" (Midwest Journal of Political Science, 1959), he set out a paradigm for the structural-functional analysis of political systems. This was followed by The American Polity (The Free Press, 1962), one of the very few applications of a functionalist approach to political science, and later by an evaluation of Parson's own contributions to political science, Sociological Analysis of Politics: The Theories of Talcott Parsons (Prentice Hall, 1967).

By the time of these publications, however, Bill's own lengthy training in economics was reorienting his thinking. In 1963 he was one of a small group of economists and political scientists who met in Charlottesville, Virginia, under the auspices of the Thomas Jefferson Center for Studies in Political Economy at a conference dubbed the "no name conference" by another participant, Vincent Ostrom. The goal was to develop what participants called variously "the pure theory of collective decision-making," "the positive theory of collective agreement," and "the theory of non-market decision making." Eventually, at Bill's suggestion, the name "Public Choice" was accepted, the Public Choice Society was founded, and the Journal for NonMarket Decision Making morphed into Public Choice.

In 1966 Bill delivered "The Shape of Political Theory to Come: From Political Sociology to Political Economy" to an American Political Science Association panel, which also included Seymour Martin Lipset, Scott Greer, and Irving Louis Horowitz. (This was published in American Behavioral Scientist in 1968 and reprinted in Lipset's 1969 edited volume, Politics and the Social Sciences.) A companion piece entitled "The New Political Economy" was published in Social Research in 1967. These papers were not only prescient but also helped to define the new field of public choice, giving coherence to the new approach and showing how the ideas of rationality and analytic individualism, imported from economics, could be brought to bear on the study of politics.

Collaborating with his wife Joyce Mitchell, Bill wrote Political Analysis and Public Policy: An Introduction to Political Science in 1969. This was an ambitious effort to incorporate what was then understood about public choice with ideas that were then only beginning to be developed in the study of public policy (the latter being Joyce's particular forte). As Joyce and Bill both gladly admitted, the book was ahead of its time-in particular, as a textbook intended to be used in the highly competitive introductory undergraduate market. Nevertheless, many political scientists who are now leaders in the discipline no less gladly admit that the book had a profound influence on their early thinking, just as many economists are also happy to admit that they learned their political science from that text. Bill's subsequent Public Choice in America (1971) and Why Vote (1971) served similar purposes.

Still working within the rational choice analytic framework that he had helped to pioneer, Bill's work became increasingly focused on policy analysis and evaluation. His early but influential paper on social security The Popularity of Social Security: A Paradox in Public Choice (American Enterprise Institute, 1977) was published long before Social Security became the hotly debated policy issue that it now is, and his The Anatomy of Public Failure (International Institute for Economic Research, 1978, with a forward by James Buchanan), addressing the problem of governmental failure as a parallel discourse to the lengthy existing literature on market failure. He asked the question that underlay his thinking for some years to come: How efficient and equitable are political processes as con- trasted with market economy processes? His answer was then, and remained, unequivocal: Political processes are basically perverse and ought not to be adopted when there is a satisfactory alternative in market-based choice. He developed the theme in several subsequent publications, including, with Randy Simmons of Utah State University, Beyond Politics: Markets, Welfare and the Failure of Bureaucracy, (Westview Press, 1994). Perhaps the most signal attribute of his writing was the capacity to take complex ideas and reduce them to simple, clear and readily understandable prose. As Mike Munger, comments, Bill had a "preternatural faculty of simplifying very complex points and being able to express them graphically. He and I published two papers together, and in both cases I found his ability to make complex theory understandable to be truly remarkable." It was also, of course, a capacity that contributed to his great classroom success throughout his career.

Two of Bill's other interests were particularly expressed in his later work. His lifelong interest in intellectual history was first expressed in his paper, with his wife Joyce, "Behavioralists and Traditionalists: Stereotypes and Self-Images" in Stephen Wasby's edited volume, Political Science: The Discipline and its Dimensions (Charles Scribner's Sons, 1970). But it was expressed in more developed form in his paper, also with Joyce, "Truman's The Governmental Process: A Public Choice Perspective, 'Micropolitics, 3: 1983) and then, most notably, in his twin papers "Schumpeter and Public Choice, Part I: Precursor to Public Choice?" in Public Choice (1984); and "Schumpeter and Public Choice, Part II: Democracy and the Demise of Capitalism: The Missing Chapter in Schumpeter," in Public Choice (1984). These papers placed both Schumpeter and the emerging discipline of public choice in historical perspective, showing how themes anticipated by Schumpeter were subsequently developed by public choice. Most recently in this vein, he published "The Old and New Public Choice: Chicago vs. Virginia" in William F. Shughart II and Laura Razzoline, (eds.) The Elgar Companion to Public Choice (Edward Elgar Publishing, 2000).

The other interest reflected his own formidable record during World War II. Particularly toward the later phases of his career, he turned to the human costs of battle, particularly in "What Price Glory? A Comparative Study of Airborne, Infantry, and Marine Casualties in Three Wars," U.S.A. Airborne (19401990: A Commemorative Volume, edited 
by Bart Hagerman (Battery Press, 1990). His personal experience was reflected in his analysis of group solidarity in airborne units during World War II, "Airborne We Fly the Sky-Paratroopers Do or Die: Rational Models of Group Solidarity," CROSSROADS: A SocioPolitical Journal, 1992. Bill took particular pride in having edited and completed (with an introduction and concluding chapter) a memoir of World War II experiences written by Kurt Gabel who served in Bill's own battalion and regiment, but who died before publication: The Making of a Paratrooper: Airborne Training and Combat in World War II, (University Press of Kansas, 1990). The book and Bill's contribution to it have been strongly praised by military historians, academics, and fellow paratroopers.

In his own community, Bill was a frequent commentator in, and letter writer to, Oregon's two major newspapers, the Eugene Register Guard and Oregonian-generally from a libertarian perspective, but always with that perspective informed by his background in public choice theory. He was also a patron of the visual arts, being well known in Eugene's and Oregon's artistic communities; and, of course, he was a connoisseur of good food, evidenced by his writing "Bill Mitchell's Restaurant Guide to San Francisco" for the annual meeting of the Public Choice Society in 1997. As all his friends knew, he was also a lifelong fan of the Green Bay Packers-and a very proud shareholder.

Joyce Mitchell was his collaborator and, as they both cheerfully acknowledged, often his most severe critic. She was also the love of his life; he saw her through her own long and difficult illness and, even after their divorce, remained her friend, supporter, and caregiver. Recovering from the heart attack he suffered after Joyce's death, he became, once again, a major daily presence in the corridors of the University of Oregon's political science department and, until only a few months before his own death, a reliable, generous, and open-minded commentator on the ideas of the many students and faculty who sought him out for reading courses, coffee, and talk. Recent students and new junior faculty, who had not known him before his retirement, discovered what earlier generations had long recognized-that he was a model of academic integrity, perspective, judgment, and enthusiasm for ideas.

Richard Kraus

University of Oregon

Jerry Medler

University of Oregon
John Orbell

University of Oregon

Priscilla Southwell

University of Oregon

\section{Lester G. Seligman}

Lester G. Seligman, professor emeritus of political science at the University of Illinois at Urbana-Champaign, died November 2, 2004, in Urbana, Illinois. He had a distinguished academic career, making major contributions to the study of political leadership and especially the U.S. presidency, and played a leadership role in the profession as well. He was widely admired, not only for the excellence of his teaching and research, but also for his indefatigable optimism, good humor, and generous spirit.

Lester was born in Chicago on February 6, 1918. He earned his B.A., M.S., and Ph.D. from the University of Chicago, the latter in 1947 following four years of military service during which he reached the rank of captain. He began his teaching career as an instructor and assistant professor at the University of Chicago, where he worked from 1947 to 1953. He then took a position at the University of Oregon, where he taught for two decades. In 1973 he returned to his home state, taking a position at the University of Illinois at Urbana-Champaign, where he was a leading member of the political science department and a productive teacher and scholar for 15 years. His energy and involvement in the profession did not decline when, at the age of 65 , he suffered a stroke that significantly impaired his speech and diminished some motor capabilities. Approaching his recovery with remarkable determination and a positive outlook, he soon resumed work and continued teaching and research until retiring, at the age of 70, in 1988. During his remaining 17 years, he continued to be engaged with the discipline, reading widely, especially on the presidency. He published his last book, The Coalitional Presidency, in 1989. He attended departmental seminars, maintained contacts with other Illinois faculty and political scientists at other institutions, and occasionally attended professional meetings. He continued to work on projects concerning the presidency until his final illness.

Throughout his latter years Lester remained physically vigorous, swimming at the university several times a week. Lester and his loving wife Judy had an active social life and were devoted to their family, frequently visiting with their children and grandchildren in Chicago and Madison. In the spring of 2004,
Lester was diagnosed with lung cancer and died several months later.

Internationally recognized, Lester held visiting positions at Harvard University's Kennedy School of Government; the Brookings Institution; the American Enterprise Institute; the Weizman Institute in Rehovot, Israel; Hebrew University in Jerusalem; the University at Aarhus, Denmark; and the University at Umea, Sweden.

The touchstone of Lester Seligman's research throughout his career was his interest in political leadership, particularly in the context of democratic governments. In more than 30 articles and four books, he inquired into the interplay among leaders, their political parties, and their staffs as they sought to lead their governments and countries. Parts of his work were broadly comparative, focusing on the development of political leadership in Israel, the varying methods by which political parties in different settings recruit candidates for office, and the ways that those methods of recruitment affect the leaders' ability to lead.

But Lester's original and abiding interest, to which he always returned, was how U.S. presidents confronted their leadership roles. He argued that the nation's ability to respond to problems and pursue agendas rested on the efforts of its elected leaders, especially its presidents. His sustained body of research on the American presidency demonstrated the validity and importance of that fundamental insight.

Several of Lester's earliest works explored the conditional nature of political leadership, especially in the American context. As he considered the presidency more specifically, he focused on key factors that affect presidents' ability to provide leadership. He examined the process by which presidents were recruited, nominated, and elected, and the consequences of changes in those processes for their ability to govern. He was especially concerned with how presidents relate to their parties and how those relationships changed in response to changes in the nomination process. He was one of the first scholars to realize and demonstrate that the shift during the 1970s from caucuses to direct primaries as the predominant method of nominating presidential candidates affected the presidents' ability to lead. Caucuses tended to tie presidents close to their parties, which enabled them to use their parties as the foundation of their governing coalitions. However, with the rise of primaries, presidential candidates began to distance themselves from their parties. This weakened parties as coalition-building mechanisms and led presidents to rely increasingly on their 
personal staffs to help them build governing coalitions.

Lester also studied the behavior of presidents in office, especially how they interacted with staff and advisors, and how those interactions affected their ability to lead. Writing in the 1950 s, he demonstrated that the presidency was becoming increasingly institutionalized. This recognition led him to examine the effects that institutionalization had on the workings of the office.

Finally, Lester showed that the policy context within which presidents attempt to assert their leadership was a key determinant of their ability to lead. He distinguished between two fundamentally different contexts - the programmatic and crisis contexts - and demonstrated through case studies that when presidents faced crises, many more resources for leadership were available and the government and people were much more receptive to following their lead. In contrast, when presidents operated in a more routine or programmatic context, they pos- sessed more limited resources and confronted a government and people concerned first with their own interests and prerogatives. All these differences made the presidents' task much more difficult.

Lester not only studied leadership, he also practiced it. He served in numerous positions in the political science profession, but his most important service to the discipline was his central role in establishing the Presidency Research Group (PRG) as an organized section of the American Political Science Association (APSA). Along with a few other leaders of the subfield, Lester conceived the need for the section, sponsored an organizational meeting, generated a constituency for the group, and secured its recognition by APSA. Lester served as the first president of the PRG from 1979-1981, subsequently served on its Executive Council, and was honored for his contributions through permanent designation as a "Founder" of the section.

To those who knew Lester Seligman, more important than all these achieve- ments and contributions was the caring and conscientious manner in which he conducted both his professional and personal life. He was demanding, both of himself and those he worked with. But behind his occasionally stern exterior was a warm and sincere individual who always had the best interests of those around him at heart. He had an infectious laugh that was heard frequently by anyone in his vicinity. He leaves behind a corps of devoted former graduate students who continue to work in many of the fields of study that he initially explored. The good nature and optimism that Lester displayed as he persevered through the difficulties following his stroke inspired those who knew him and stand as a testament to his good will and positive outlook. He is and will be missed.

Cary R. Covington University of Iowa Paul J. Quirk

University of British Columbia 